\title{
Constructing a quasi-professional educational environment as a condition of future teachers' professional and communicative competence formation
}

\author{
I.P. Selezneva ${ }^{1 *}$, N.V. Gorbova ${ }^{2}$, and S.N. Perederii ${ }^{3}$ \\ ${ }^{1}$ Krasnoyarsk State Pedagogical University named after V.P. Astafiev, Krasnoyarsk, Russia \\ ${ }^{2}$ V.I. Vernadsky Crimean Federal University, Simferopol, Russia \\ ${ }^{3}$ V.I. Vernadsky Crimean Federal University, Simferopol, Russia
}

\begin{abstract}
The article examines the conditions of constructing future teachers' (currently B.A. students') professional and communicative competence in the context of modernization of the present-day system of higher education, which stipulate the need to rethink the concept of future professionals' competence and the transition from sector-specific professional competencies to meta-competencies of a wider scope associated with the peculiarities of professional and communicative communication. Following on from the theoretical and methodological analysis, it is concluded that the construction of a quasi-professional educational environment reconstituting the conditions of professional communication can be organized in the form of solving situational case problems using such technologies as subject-language integrated learning, blended learning visualization and podcasting. The methodological validity of the proposed scientific research results on constructing a quasiprofessional educational environment to form future teachers' professional and communicative competence has been confirmed by the results of their evaluation at the Humanitarian and Pedagogical Academy (branch) of Vernadsky Crimean Federal University (Yalta) and Krasnoyarsk State Pedagogical University named after V.P. Astafiev (Krasnoyarsk).
\end{abstract}

\section{A problem statement}

In the continuous globalization context, it has become essential to modernize the system of education in general and higher education in particular. As the majority of the EU countries and the Russian Federation have adopted the Bologna Agreement, it seems unavoidable to use the concept of sustainable development in the educational process at higher education institutions. This concept provides for the use of innovations in future specialists' professional training $[1,2]$. The priorities of future teachers' training are changing: more attention is paid to the development of meta-competencies, practice-oriented learning and

*Corresponding author: prof-ped.gpa@mail.ru 
the formation of the professional communication ability [3]. The blended learning and flipped classroom technologies have proved effective and are finding way into distance learning during the COVID-19 pandemic [4].

Nevertheless, the use of the competence-based approach both in Russia and abroad is associated with a number of problematic issues that are still to be resolved: despite the available theoretical research into the problem of meta-competencies' formation $[5,6]$, there are still no technologies for their formation in future teachers' practice-oriented education. No algorithms have been developed for teaching activities that promote adaptation to the chosen profession and develop students' professional and communicative activity. The professional and communicative competence can be formed and developed in the process of implementing quasi-professional activities through the use of innovative technologies for its modeling [7, 8, 9]. The key problem of the research is to study the potential of a quasi-professional educational environment as one of the conditions of future teachers' professional and communicative competence formation.

\subsection{The objective of the work}

The above-mentioned problem attracts the attention of a number of Russian and foreign researchers, but most of them have offered a theoretical substantiation of the problem or hypothetical ways to solve it. On the basis of the studied theoretical material, we have developed and practically tested a number of recommendations for constructing a quasiprofessional educational environment to form future teachers' professional and communicative competence. The theoretical and methodological basis of the experiment includes the scholarly works by V.A. Adolf, E.K. Dashkova, O.G. Byrdina, E.A. Yurinova, S.G. Dolzhenko, V.V. Epaneshnikov, Ju.A. Moiseeva, O.L. Felde, O.N. Igna, G. Czerniawski, D. Gray, A. MacPhail, Y. Bain, P. Conroy, A. Guberman, J.D. Martínez, A. Schalk-Trietchen, F. Wolff, C. Borzikowsky, etc.

Conducting the experimental part of the research, the authors also relied on their own research results on the above-mentioned topic tested at the preliminary stage of the research $[10,11]$. This has made it possible to determine the conceptual elements of the theoretical and practical research base and to reveal the validity of the developed methodology.

\section{Results of the research}

Figures and tables, as originals of good quality and well contrasted, are to be in their final form, ready for reproduction, pasted in the appropriate place in the text. Try to ensure that the size of the text in your figures is approximately the same size as the main text $(10$ point). Try to ensure that lines are no thinner than 0.25 point.

To achieve the goal of the research, the following tasks were defined:

- identifying the specifics of future teachers' professional and communicative competence which should be formed in the process of educational activity;

- studying the theoretical and practical experience of future teachers' quasi-professional training at higher education institutions;

- determining methods and technologies for constructing a quasi-professional educational environment;

- developing recommendations on the usage of the selected methods and technologies to form future teachers' professional and communicative competence;

- conducting an experiment to test the developed recommendations;

- using the questionnaire method to reflect the obtained results. 
The methodological capacity of the quasi-professional educational environment has been studied both in Russian and foreign scientific works. F.J. Pozuelos Estrada, F.Ja. García-Prieto and S. Conde-Vélez describe the changing strategies of higher education focused on future professional activities [12]. The construction of the quasi-professional educational environment at higher education institutions allows solving the problem of students' adaptation to their professions. According to V.A. Adolf and E.K. Dashkova, it will help future professionals to avoid irrational intensification of the educational process and painlessly go through the process of professional socialization. The inability to organize professional and communicative communication or cope with stress factors often leads to rapid professional burnout and thereby reduces specialists' competitiveness [13]. M.V. Kochetkov and E.M. Chebotareva propose to take into account higher education students' professional activity and their intellectual maturity, considering the essential characteristics of the modern higher education's creative and innovative paradigm [14]. V.V. Ignatova and T.N. Pasechkina describe the relationship between professional selfdetermination and future specialists' communicative qualities [15]. K.L. Rose and A. Schalk-Trietchen focus on the formation of future specialists' readiness to fulfill their personal potential in profession and career $[16,17]$.

The problem of the formation of communicative competence is considered in detail by A.A. Isakova, F. Wolff, C. Borzikowsky, F.J. Pozuelos Estrada, F.Ja. García-Prieto and S. Conde-Vélez. A.A. Isakova emphasizes that the communicative education system should be continuous, complex, interdisciplinary and integrated, its differentiation depending on vocational guidance [18]. F. Wolff and C. Borzikowsky describe communicative competence as a complex of abilities necessary for adequate and effective interaction highlighting the intercultural communicative competence [19].

The Content and Language Integrated Learning (CLIL) technologies are widely used to create a quasi-professional educational environment and have won acceptance both in Russian and foreign teaching techniques $[20,21,22]$. In this case, professional integration occurs due to the combination of subject and linguistic spheres of communication.

Having studied the research works of theoretical and practical experience of future teachers' quasi-professional training at higher education institutions, we can come to the following conclusion: it is necessary, first of all, to mention the multistage nature of future teachers' quasi-professional training. We consider professional communication skills to be teachers' integrative characteristic feature comprising a system of professional-subject, professional-technological and professional-personal competences. These are expressed in the ability to succeed in professional communication.

In order to conduct the experiment, a number of students at the Humanitarian and Pedagogical Academy (branch) of the V.I. Vernadsky Crimean Federal University (Yalta) and Krasnoyarsk State Pedagogical University named after V.P. Astafyev (Krasnoyarsk) were divided into the control and experimental groups. The experiment involved 98 students majoring in pedagogical education (40 in Yalta and 58 in Krasnoyarsk). The experiment included three stages: preparatory, substantive and activity. Reflection was carried out at the productive stage.

The preparatory stage of the experiment focused on the formation of students' motivational and value attitude to mastering professional and communicative strategies and tactics; attracting students to active work through the introduction of interactive and multimedia learning technologies; identifying the initial level of students' professional and communicative competence.

The substantive stage involved students' assimilation of communicative knowledge in the process of studying meaningfully updated professional academic courses. The activity stage focused on students' purposeful accumulation of practical quasi-professional experience, creative comprehension and use of the theoretical knowledge gained through 
the implementation of various interactive technologies. The productive stage aimed at students' reflection and understanding of the acquired professional experience under the conditions of quasi-professional activity and monitoring the changes in the levels of professional and communicative competence.

Of all the variety of interactive methods and forms, preference is given to the most significant ones in the context of future teachers' professional activity, primarily professionally-oriented situations: «Pedagogical interaction with students», «Pedagogical interaction with colleagues», «Pedagogical interaction with administrators» and «Pedagogical interaction with parents».

The interactive methods aim at:

- activation of students' quasi-professional activity;

- development of the ability to work in small and big groups - social skills' improvement;

- actualization of the ability to accept the «role» of the Other;

- improvement of the analysis and introspection skills, thus, developing reflection.

The process of involving students in the discussion of professionally-oriented situations is carried out successively - in several stages: from the stage of «entry» to the stage of «discussion» and then to the stage of «team expert evaluation».

The «entry» stage is introduced in the online mode in which students learn the theoretical materials of professionally-oriented situations and get acquainted with a situation or a description of a certain type of pedagogical interaction in order to solve professional and communicative problems. The prospects for the use of innovative technologies in distance learning are discussed in [23]. The authors of the research contend that asynchronous online webinars present an effective tool in professional training featuring several obvious advantages. These include students' possible feedback and accessibility combined with temporal flexibility. It stands to reason that students may find it more convenient to study at their own pace and pause at any time.

The «discussion» stage involves the direct solution of professionally-oriented situations in the offline mode. The discussion of professionally-oriented situations, firstly, allows superimposing the communicative knowledge acquired during the «entry» stage on the «canvas» of future teachers' specific professional communication; secondly, it contributes to the enrichment of the experience of their socio-cultural interaction with the Other (s). When discussing situations, students must understand and assess the situation, determine the essence of the problem and develop an appropriate mode of behavior to solve it through the use of appropriate interactive strategies and tactics. Students' involvement in the discussion of situations is facilitated by the use of interactive methods: «PRES Method», «Aquarium», «Two, four - all together», «Brainstorming», etc.

According to the «Brainstorming» interactive technology, in order to solve a problematic issue presented in a professionally-oriented situation, students need to find as many solutions as possible, each of which being noted on a piece of paper or a blackboard. The creation of a kind of "suggestion box» is followed by the analysis and discussion stages.

When using the «Aquarium» technology, students are united in groups of 5-6 members. The students of the 1st group take their place in the center of the room and get access to the gist of the situation that the group members need to discuss. The rest of the students should closely follow the process of discussion, making, if necessary, some notes, but they do not have the right to interfere in the course of the discussion. At the end of the public discussion of the professionally-oriented situation, the members of the group take their usual seats, and all the other «listening participants» discuss the course of their talk and the proposed arguments. Then, another group takes its place in the «Aquarium» and starts discussing another situation. 
In the course of the interactive exercise «Two, four - all together», students are offered a professionally-oriented situation, which they first discuss in pairs and then in a group of four. After the final decision is reached by the group of four students, a joint discussion of the situation starts.

Thanks to the «PRES method», future teachers develop the ability to formulate statements on a specific discussion topic, which is concisely and justifiably covered in a professionally-oriented situation. The interactive exercise has four steps:

- expressing one's own opinion («I suppose that ...»);

- justifying one's thought ( «... since ...»);

- using examples and arguments to support one's viewpoint («For example,..») and generalizations («So ...»). At the stage of «collective examination», the results of the work are summed up first in small groups, and then they are presented for collective discussion. The teacher is given the right to express his or her viewpoint.

At the initial stage of the experimental work, the level of students' professional and communicative competence in the experimental and control groups was determined with the help of questionnaires and a specially designed test. To eliminate the element of randomness when choosing answers in the test, we used double questions, repeating the content of the previous question in a modified version. The use of auxiliary methods (questionnaires) was justified by the need to obtain more reliable data about the level of professional and communicative competence.

As can be seen in Table 1, the levels of professional and communicative competence changed upon the experiment's completion: the experimental groups, in comparison with the control group, began to lead for all the indicators. Table 1 shows the comparative data of the students' levels in the experimental group at the beginning and the end of the experiment. These data indicate that the number of students with the best possible level of professional and communicative competence increased in the EG from $3 \%$ to $7 \%$; the share of students with an acceptable level of professional and communicative competence increased in the EG from $24 \%$ to $41 \%$.

Table 1. Summary table of the levels of students' professional and communicative competence in the control and experimental groups at the beginning and the end of the experiment (\%).

\begin{tabular}{|c|c|c|c|c|c|c|c|c|}
\hline \multirow{3}{*}{$\begin{array}{c}\text { Levels of } \\
\text { profession } \\
\text { al and } \\
\text { communic } \\
\text { ative } \\
\text { competenc } \\
\text { e } \\
\end{array}$} & \multicolumn{4}{|c|}{ EG } & \multicolumn{4}{|c|}{ CG } \\
\hline & \multicolumn{2}{|c|}{$\begin{array}{l}\text { Beginning of the } \\
\text { experiment }\end{array}$} & \multicolumn{2}{|c|}{$\begin{array}{l}\text { End of the } \\
\text { experiment }\end{array}$} & \multicolumn{2}{|c|}{$\begin{array}{l}\text { Beginning of } \\
\text { the experiment }\end{array}$} & \multicolumn{2}{|c|}{$\begin{array}{c}\text { End of } \\
\text { the experiment }\end{array}$} \\
\hline & $\begin{array}{c}\text { Yalt } \\
\text { a }\end{array}$ & $\begin{array}{c}\text { Krasnoyar } \\
\text { sk }\end{array}$ & $\begin{array}{c}\text { Yalt } \\
\text { a }\end{array}$ & $\begin{array}{c}\text { Krasnoyar } \\
\text { sk }\end{array}$ & $\begin{array}{c}\text { Yalt } \\
\mathbf{a}\end{array}$ & $\begin{array}{c}\text { Краснояр } \\
\text { ск }\end{array}$ & $\begin{array}{c}\text { Yalt } \\
\text { a }\end{array}$ & $\begin{array}{c}\text { Krasnoyar } \\
\text { sk }\end{array}$ \\
\hline $\begin{array}{l}\text { Best } \\
\text { possible }\end{array}$ & 3.2 & 4.1 & 20.3 & 19.4 & 4.2 & 3.4 & 5.2 & 6.6 \\
\hline Acceptable & 24.5 & 25.6 & 55.6 & 52.4 & 27,1 & 25.3 & 30.7 & 34.3 \\
\hline Critical & 62.5 & 70.3 & 24.1 & 28.2 & 69.7 & 71.3 & 64.1 & 59.1 \\
\hline
\end{tabular}

The experimental results presented in Table 1 demonstrate the positive effect of using a quasi-professional environment for the formation of students' professional and communicative competence:

- 20.3\% (Yalta) and 19.4\% (Krasnoyarsk) experimental groups reached the best possible level of professional and communicative competence;

- 20.3\% (Yalta) and 19.4\% (Krasnoyarsk) of students in the experimental groups reached the best possible level of professional and communicative competence;

- 55.6\% (Yalta) and 52.4\% (Krasnoyarsk) of students in the experimental groups reached the acceptable level of professional and communicative competence; 
- 24.1\% (Yalta) and 28.2\% (Krasnoyarsk) of students in the experimental groups remained at the critical level of professional and communicative competence.

The data obtained during the experiment can lead to the conclusion that it is effective to construct a quasi-professional environment in order to form students' professional and communicative competence.

\section{Conclusions}

The results obtained in the course of the research make it possible to draw a number of conclusions regarding the use of the quasi-professional environment for the formation of students' professional and communicative competence. First, quasi-professional activity is one of the conditions for students' success in their future professional activity, since it allows students evaluating their own advantages and disadvantages as future managers and moderators of professional communication.

Secondly, the modeling of quasi-professional activity in the implementation of the educational process at higher education institutions contributes to the formation and development of students' meta-competencies, which include professional and communicative competence.

Thirdly, the use of interactive methods and technologies imitating professionallyoriented situations in the process of future teachers' professional training activate and improve the social skills necessary for further professional activity. Thus, the professional and communicative self-determination of future specialists is carried out.

Judging from these conclusions, we consider it possible to contend that the use of a quasi-professional environment for the formation of students' professional and communicative competence is effective.

\section{References}

1. V.I. Kirko, E.S. Kononova, Education as a key factor of innovative and steady development, Modern education, 1, 12-24 (2019)

2. J. Zajda, V. Rust, Research in globalisation and higher education reforms. Globalisation and higher education reforms, Globalisation comparative education and Policy research, 15, 179-187 (2016)

3. G. Czerniawski, D. Gray, A. MacPhail, Y. Bain, P. Conroy, A. Guberman, The professional learning needs and priorities of higher-education-based teacher educators in England, Ireland and Scotland, Journal of Education for Teaching, 44 (2), 133-148 (2018)

4. A. Sun, X. Chen, Online Education and Its Effective Practice: A Research Review, Journal of Information Technology Education: Research, 15, 157-190 (2016)

5. V.V. Gorshkova, Phenomenological understanding of the competence concept in the system of higher professional education in Russia, Pedagogical Journal, 6, 147-162 (2015)

6. V.A. Shershneva, M.V. Osipov, Metacompetency status in competency hierarchy, The Bulletin of KSPU named after V.P. Astafiev, 1(51), 80-89 (2020)

7. V.V. Epaneshnikov, Implementation of quasiprofessional educational environment training school teachers, Kasan Pedagogical Journal, 4(117), 76-80 (2016)

8. Ju.A. Moiseeva, Approach to modeling students quasiprofessional activity, Jaroslavskii pedagogicheskii vestnik, 5(110), 74-80 (2019) 
9. O.L. Felde, O.N. Igna, Quasi-professional tasks in methodical training of a foreign language teacher, Vestnik TGPU, 10(187), 155-159 (2017)

10. N.V. Gorbova, I.P. Selezneva, The development of foreign language communicative competence of students using the technology of podcasting, Problems of modern pedagogical education, 61(2), 122-126 (2018)

11. I.A. Mayer, I.P. Selezneva, Master's programs in the foreign language education field: modeling quasi-professional educational environment, The Bulletin of KSPU named after V.P. Astafiev, 3(53), 93-103 (2020)

12. F.J. Pozuelos Estrada, F.Ja. García-Prieto, S. Conde-Vélez, Learning styles in university students: types of strategies, materials, supports, evaluation and performance, Case study, European journal of contemporary education, 9(2), 394-416 (2020)

13. V.A. Adolf, E.K. Dashkova, Adaptation of high school students to future professional activity, Siberian Pedagogical Journal, 1, 61-67 (2017)

14. M.V. Kochetkov, E.M. Chebotareva, Creative and innovative educational paradigm and acmeological approach to the development of a student as a subject of professional activity, Journal of Siberian Federal University. Humanities \& Social Sciences, 10(2), 177-188 (2017)

15. V.V. Ignatova, T.N. Pasechkina, Communicative self-efficacy as the most important quality of the future specialist, Theoretical \& Applied Science, 5(49), 161-164 (2017)

16. K.L. Rose, Taking Control: Self-directed Professional Development and Teacher Agency, Teacher Learning and Professional Development, 5(1), 62-78 (2020)

17. A. Schalk-Trietchen, Sicherheit gewinnen und (sich) verändern. Evaluation als Erfahrungsschatz für Professionalisierung nutzen, Zeitschrift Pädagogik, 5, 16-19 (2017)

18. A.A. Isakova, Retrospective analysis of communicative competence development, Integration of Education, 21(1), 46-53 (2017)

19. F. Wolff, C. Borzikowsky, Intercultural Competence by International Experiences? An Investigation of the Impact of Educational Stays Abroad on Intercultural Competence and Its Facets, Journal of Cross-Cultural Psychology, 49(3), 488-514 (2018)

20. O.G. Byrdina, E.A. Yurinova, S.G. Dolzhenko, Developing foreign language professional-communicative competence of pedagogical university students by means of CLIL, Education and Science, 22(7), 77-100 (2020)

21. J. Collett, The Linguistic Garden: A Case Study of an Emergent Bilingual's Participation, Positioning and Identity Development in a Dual Language Program, Journal of Language, Identity \& Education, 18(4), 236-250 (2019)

22. J.D. Martínez, Which instructional programme (EFL or CLIL) results in better oral communicative competence? Updated empirical evidence from a monolingual context, Linguistics and Education, 51, 69-78 (2019)

23. V.V. Dobroselkiy, S.P. Peredery, I.A. Erina, Prospects for the Use of Innovative Offline Technologies in Distance Teaching Students Majoring in Management, The world of science, culture and education, 5(84), 162-165 (2020) 